and trade secrets, as many of us have found, impede the research man, though, of course, there are two sides to the question.

r919-The Use of Water Glass to Prevent Rust. A question that apparently can be answered by somebody, but the answer not found as yet; hence we are minded of the question box, the ways and means of readily advertising the unanswered question, and thus of getting in touch with sources of needed information.

More questions illustrating one point or another could readily be cited; but let these seven suffice to suggest how much more a library service is than a general or special collection of books, periodicals, indexes, and a staff to consult them.

What can this convention do to perfect the ways and means of getting information? Can it, by resolution, encourage the librarians of the country, through the American Library Association (having headquarters at 78 East Washington Street, Chicago), to act as a great clearing house of information and of research? I believe that those headquarters would, if appealed to in this capacity, take adequate means to build up a service that would give sensitive response to seekers for information who have not been successful through local resources.

Perhaps a very simple way to stimulate the big library industry I have hinted at, is for each delegate here to-day to remember to send to the American Library Association headquarters at least one question that he has found to be a puzzler, with the expectation that the Association will show itself eager to render the service of securing the answer. It would be well to include return postage with the question. If satisfaction is not obtained by this means, then, as sponsor for the suggestion, I would ask to be informed of the fact myself; and if I am thus informed before the middle of June, it should be in time for me to report the complaint to the general convention of librarians, which is to be at Asbury Park the last week in June.

\section{WORK OF THE LIBRARY OF THE SOLVAY PROCESS COMPANY}

By W. L. Nerti, Solvay Process Co., Syracuse, N. Y.

The collecting of books and journals for this Company began more than thirty years ago. Ours is particularly a special library, mainly on chemical subjects, which contains some r 200 volumes, including bound volumes of the principal English and German chemical journals for some years past. It is in constant use by our staff of chemists. It is indexed on the Dewey system, with the usual cards.

We have also, as a second part of the library, files of the principal technical journals, both American and foreign. From these we make abstracts, which are printed and sent out to about Ioo men in our employ, one-half of whom are in the local office and one-half in our other works: We also circulate among the officials here about twenty of the journals, which are carried out and brought in daily after two days' use.

\section{SPECIAL LIBRARY SERVICE IN THE BARRETT COMPANY}

Not only has this firm realized the value to be derived from a permanent library service bureau with headquarters in the main office but has recognized the necessity for attaching to the personnel of the Research Laboratory a "library chemist" whose time is exclusively devoted to the compilation of literature references pertaining to subjects under investigation or to be investigated. The bibliographies thus compiled are put into ring binders, each abstracted reference having its separate sheet. The main classification of the references is chronological and each year is again classified alphabetically by authors. Classification is followed by pagination and then the bibliography is ready for the preparation of both author and subject indexes. The subject index is cross-indexed to the minutest detail and some- times covers as much as 15 pages for a bibliography of I5o to 250 pages.

The above remarks are not intended to serve as an outline of our Research Information Service, but are merely given to illustrate our view as to the simplicity and serviceability of any such scheme.

\section{LIBRARY SERVICE IN THE CHEMICAL DEPARTMENT AND CHEMICAL DEPARTMENT LABORATORIES OF E. I. DU PONT DE NEMOURS \& COMPANY}

By F. L. Gallup, E. I. du Pont de Nemours \& Co., Wilmington, Del.

In answer to a request for a paper describing any special features of the library of the chemical department of $E$. I. du Pont de Nemours \& Company which are helpful to us or may be helpful to others, it is necessary to describe briefly the library organization in the chemical department of the Company.

The department is composed of some ten divisions whose executive heads are in the main office of the Company. The department maintains, outside of the city of Wilmington, four experimental laboratories, each of which is in itself a large organization. Each of these laboratories has a library and a librarian.

Each of the five libraries of the department is a special library and really special wnto itself for the following reason. Particular lines of work are delegated to each laboratory organization which may be briefly summarized as follows:

EXPERIMENTAL STATION-Smokeless powder, black powder, artificial leather, and some special chemicals.

EASTERN IABORATORY-Commercial dynamites and high explosives.

JACKSON LABORATORY-DYES.

DELTA LABORATORY-Pyralin products and pyroxylin compositions.

It is natural that each library should specialize along the lines its men are interested in. The Main Office Library functions for the executives who direct the activities of the several laboratories and as a result the Main Office Library directs its attention more particularly to the broader aspects of the subjects the department is interested in and less to material required in laboratory investigation and routine.

The Main Office Library of the department has no authority in the direction of the other libraries but a serious effort is made among the several libraries to coöperate, each to be helpful to the others as occasion permits. This coopperation is a very hearty one and much good comes from it.

Our library organization is not old, in fact is comparatively young, but a serious effort is being made to develop our libraries along common-sense lines and to have as librarians those who know not only the principles and rules of library economics, but who can study their problem from the service standpoint and discount the requirements of the library to the extent of anticipating the needs of the chemists on old and new problems.

We believe in this connection that it is of decided importance to have means provided by executive heads which shall supply a librarian serving industrial laboratories as promptly as possible with as much information as possible to aid in placing in the library needed information on new subjects for investigation in the laboratory. It is of prime importance to provide, as far as possible, in advance, library requirements of an industrial laboratory. It is a source of added stimulation to the investigator to be able to find his information at hand at the time wanted and not to have to wait until it is ordered and received and perhaps in the meantime have led himself into unnecessary expenditure of time in trying to produce the information through laboratory experiments, or lost in some degree his enthusiasm.

There are several features in our library organization that are particularly helpful. There is a monthly exchange of accession 
reports between the five libraries of the department. A review of these may bring to the attention of the libraries material that had been overlooked in the routine review of current publications. There is prepared and distributed to the libraries a very complete monthly compilation of abstracts which have to do particularly with those subjects in which the chemists of the department are interested. We believe that this is an especially valuable aid to an industrial laboratory in that the efforts of one person are directed to supply specific information, digested and classified, to relieve the busy chemist of the necessity of reviewing periodic literature. He may, through the perusal of this publication, direct his attention to only those matters which are of moment.

Atother important feature which is undergoing development and perhaps has reached a higher stage of usefulness in our Main Office Library than in our laboratory libraries, is the maintenance of patent files covering the subjects in which the department is interested. The patents are filed in the vertical files in their numerical order, are catalogued according to author and subject, and a numerical card index' is maintained which allows the librarian or her assistants at a glance to answer'phone inquiries in regard to our patent resources. We must recognize the development of the prior art in its relation to present-day chemical research and a review of the patent situation, we believe, is quite as important a feature as the review of literature. For this reason we believe that an essential feature in the library service in the industrial laboratory is the maintenance of careful cataloguing and filing of patents issued on the subjects in which the laboratories are interested. We charge out and credit the return of patents in exactly the same way as books and periodicals are charged and credited.

Another helpful feature is the maintenance in the catalogue of each library of a record of the resources of the other four libraries. This is economically and readily maintained by placing on the card distinguishing letters which represent the other libraries and having a distinguishing color card with distinguishing letters for those items which are not a part of the resources of the home library. This puts before each librarian a nearby source for material which may be urgently needed.

We are getting ready to organize and maintain a "special research" catalogue of references. The ground work is being laid to make this a valuable adjunct to the library service in the five ibraries. This effort will include the classification and indexing of the information in our chemical department reports which are prepared by special investigators. This work may not perhaps be properly classed as library work but we maintain that in an industrial laboratory the library must be turned to as the chief source of information of a technical character. A great many instances have arisen, particularly during the recent emergency, which have shown that it is highly desirable to maintain an index of classified information covering the results of work that our men have done as distinguished from indexed classified information obtained from sources outside of our own laboratories.

New men come with us who may be put on problems that have been previously undertaken and temporarily dropped, or work may be required on problems that were thought to have been finished several years ago. We believe it is essential to have in the libraries, readily available, a classification of the results of work previously done in order to avoid unnecessary duplication of effort which means loss of time and unnecessary expenditure of money. Another feature which is being developed in our Main Office Library and which may be extended to our laboratory libraries is to compile our catalogue in such a way that it will give the user information in the way our men naturally look for it in view of the nature of the subjects we have to deal with. We believe that any material worth keeping is worth cataloguing and the catalogue should be a directory to all the resources of the library. Many instances have come to our attention to show that a "one man" system is not of much value if the "one man" dies or is suddenly removed from his position, and we are bending our efforts to produce a system of classification and indexing in our libraries which will be self-explanatory.

One of our libraries has a member on its staff who is engaged in bibliographical work on subjects under investigation. You will appreciate the value of a person capable of doing this kind of work in the library staff which serves an experimental laboratory engaged in a wide range of activities. The advantage is self-evident. Not only may the chemist's time be devoted to his actual work but the search of the literature is in the hands of one trained to this kind of work.

It goes almost without saying that a feature in library service at the laboratory which must not be overlooked is the employment of those to conduct the library who have an enthusiasm for technical work and who have a disposition to encourage a research chemist to feel that an effort is being made to put the resources of the library at his disposal in the most convenient way. It is truly stimulating to feel that the library corps is willing to be of service, and the selection of a librarian who has the ability to study the dispositions of the people whom she serves, as well as the pure library problems, is to be very much encouraged.

\section{FOREIGN INDUSTRIAL NEWS}

\section{By A. MCMIIIAN, 24 Westend Park St., Glasgow, Scotland}

\section{SOUTH AMERICAN TRADE}

According to the Times Trade Supplement for March, the Republic of Ecuador offers a very attractive field for most kinds of manufactured articles. Practically anything that the country requires - except food-has to be imported, since there are hardly any local manufacturers. The purchasing power of the inhabitants may not be great, but the custom is good, because all transactions are done in cash and the mining trade in the country has lately flourished greatly. In addition to articles of apparel, building materials, for example, iron, steel, and cement, are largely in request, the market being steady all the year round. Wood is not imported as a soft white oak grows in abundance, but most kinds of implements, tools, and ironmongery, are in great demand and, up to the beginning of the war, the Germans had this in their hands. In Chile, where agriculture is chiefly developed, there should be a ready market for farming machinery. Effective demonstration would be needed but once they were convinced of the merits of the farm tractor, the question of expense would not stand in the way of the wealthy ranch-owners. There is also considerable scope for irrigation equipment, engine-piping, etc. Chief among the agricultural implements imported last year were cultivators and ploughs. Other articles of machinery, apart from sugar refining machinery, which found a market, were mowers, reapers, threshers, planters, and seeders.

\section{LARGEST MOTOR MADE}

What is claimed to be the largest motor made, says Engineer, I27 (I919), 20I, has recently undergone its trials at the Stafford works of Siemens Bros., England. It is a direct current machine of 20,000 horse power and is to be used in drawing a rolling mill. The machine is virtually three separate motors on one shaft and weighs about 300 tons. Current is supplied to it at 440 volts. 